\title{
UPLIFT - ILGALAIKIŲ LĖTINĖS OBSTRUKCINĖS PLAUČIŲ LIGOS GYDYMO TYRIMŲ GAIRĖS
}

\author{
PROF. DR. RAIMUNDAS SAKALAUSKAS \\ KMU PULMONOLOGIJOS IR IMUNOLOGIJOS KLINIKA
}

\begin{abstract}
$2008 \mathrm{~m}$. spalio $5 \mathrm{~d}$. Berlyne vykusiame Europos respiratologų draugijos (ERS) kasmetiniame kongrese buvo viešai paskelbti UPLIFT $^{\oplus}$ (angl. Understanding Potential Long-term Impacts on Function with Tiotropium) tyrimo rezultatai.

UPLIFT $^{\oplus}$, viename didžiausių kada nors atliktų lètinès obstrukcinès plaučių ligos (LOPL) tyrimų, dalyvavo 5993 LOPL sergantys pacientai iš 490 tyrimo centrų 37 pasaulio šalyse, iskaitant Lietuvą. Tyrimui vadovavo profesorius Marc Decramer, Belgijos Liuveno (Leuven) mieste esančio Katalikų universiteto ligoninės Pulmonologijos skyriaus vadovas.
\end{abstract}

Tiriamųjų kontingentas - ne jaunesni kaip 40 metu pacientai, kurių forsuotas iškvepimo tūris per pirmąją sekundę $\left(\mathrm{FEV}_{1}\right)$ neviršijo 70 proc. būtinojo dydžio bei jo santykis su forsuota gyvybine plaučiu talpa $\left(\mathrm{FEV}_{1} / \mathrm{FVC}\right)$ neviršijo 70 proc. po bronchus plečiančiu vaistu (ipratropiumo ir albuterolio) inhaliacijų. Tiriamųju su sveikata susijusiai gyvenimo kokybei įvertinti buvo naudojamas šv. Jurgio ligoninès klausimynas (angl. St. George's Respiratory Questionnaire, SGRQ).

Šiame itin plačios apimties atsitiktinių imčiuc placebu kontroliuojamame dvigubai aklame paraleliu grupių 4 metų trukmès tyrime lygintas tiotropio, vartojamo po $18 \mu \mathrm{g}$ vieną kartą per dieną, ir placebo poveikis LOPL (nuo vidutinio sunkumo iki labai sunkios) sergantiems pacientams. Tiriamiesiems leista vartoti kitus jiems gydytojų skirtus kvèpavimo takus veikiančius vaistus, išskyrus inhaliuojamuosius anticholinerginius.

I tyrimą ittraukti atsitiktinai atrinkti pacientai pakartotinai buvo tiriami po 1 mén., po 3 mèn., o vèliau kas 3 mèn. 4 metu laikotarpiu.

46 proc. tyrime dalyvavusiu pacientu buvo nustatyta antra ligos stadija pagal GOLD. Tai viena didžiausių kada nors tirtų antros stadijos LOPL sergančių ligonių grupių. Ši stadija labai svarbi klinikiniu požiūriu, nes būtent nuo tada ligonius pradeda varginti pirmieji LOPL simptomai.

\section{TYRIMO REZULTATAI}

\section{Plaučių funkcijos mažèjimo greitis}

Vidutinis pobronchodilatacinis $\mathrm{FEV}_{1}$ greičiau mažèjo pacientams, kurie pirma numatyto laiko nutraukè gydymą $(55 \pm 4 \mathrm{ml} / \mathrm{m}$. tiotropio grupëje ir $57 \pm 4 \mathrm{ml} / \mathrm{m}$. placebo gru- peje), palyginti su pilnutinai programa jivykdžiusiais pacientais $(38+1 \mathrm{ml} / \mathrm{m}$. tiotropio grupejje ir $40 \pm 1 \mathrm{ml} / \mathrm{m}$. placebo grupeje).

Vertinant gydymo poveiki vidutiniam ikibronchodilataciniu ir pobronchodilatacinių FEV ir FVC rodmenų mažèjimo greičiui nuo 30-tos dienos iki gydymo pabaigos, skirtumo tarp grupiu nenustatyta

Tiotropio grupèje vidutiniai ikibronchodilatacinio ir pobronchodilatacinio $\mathrm{FEV}_{1}$ rodmenys reikšmingai pagerejo ir išliko didesni visuose tyrimo etapuose po atsitiktinès atrankos. Analogiškas palankus tiotropio poveikis nustatytas ir vertinan FVC kitimus. Vidutinis $\mathrm{FEV}_{1}$ prieš bronchodilatatoriu inhaliavimą tiotropio grupeje padidejo nuo 87 iki $103 \mathrm{ml}$, po jo - nuo 47 iki $65 \mathrm{ml}$, palyginti su placebu ( $<<0,001)$.

Išanalizavus 1554 pacientú, kurie tyrimo pradžioje nevartojo inhaliuojamujų gliukokortikosteroidu arba ilgai veikiančių beta 2 agonistu, spirometrijos duomenis, nustatyta, kad tiotropio vartojusiu pacientu vidutinio pobronchodilatacinio $\mathrm{FEV}$ mažèjimo greitis buvo mažesnis $(40 \pm 3 \mathrm{ml})$, palyginti su placebo grupe $(47 \pm 3 \mathrm{ml}, \mathrm{p}=0,046)$.

3421 pacientui vidutinis ikibronchodilatacinio $\mathrm{FEV}_{1}$ mažejjimo greitis nuo tyrimo pradžios iki 30 dienos po tyrimo reikšmingai nesiskyrè tarp tiotropio (15 $\mathrm{ml} / \mathrm{m}$.) ir placebo grupiu $(17 \mathrm{ml} / \mathrm{m}$.) (p $=0,25)$. Tačiau ivertinus 3418 pacientu kurie techniškai gerai atliko pobronchodilatacinę spirometriją, duomenis, vidutinis pobronchodilatacinis $\mathrm{FEV}_{1}$ mažejo statistiškai reikšmingai lèčiau tiotropio grupèje $(27 \mathrm{ml} / \mathrm{m}$.), palyginti su placebo grupe (32 $\mathrm{ml} / \mathrm{m} . ; \mathrm{p}=0,01)$.

\section{Su sveikata susijusi gyvenimo kokybė}

Tiotropis statistiškai reikšmingai pagerino SSSGK, vertintą pagal ŠJKK ( $p<0,001)$. Ivairiais 4 metu tyrimo laikotarpiais pacientuc, vartojusiu tiotropio, gyvenimo kokybė buvo geresnè nei tyrimo pradžioje - bendras vidutinis ŠJKK balų skaičiaus sumažejiimas bet kuriuo laikotarpiu buvo 2,7 (95 proc. PI 2,0-3,3) ( $<<0,001$ ).

Gydant tiotropiu daug didesnei daliai pacientu, palyginti su placebo grupe, SSSGK pagerèjo kliniškai reikšmingai ( $t$. y. balu suma sumažèjo $\geq 4$ balais): po 1 metu atitinkamai 49 proc. ir 41 proc., po 2 metu - 48 proc. ir 39 proc., po 3 metu 46 proc. ir 37 proc., po 4 metu -45 proc. ir 36 proc. (visais atvejais $\mathrm{p}<0,001$ ).

\section{Paūmèjimai}

Gydant tiotropiu, statistiškai reikšmingai (4,1 ménesio), palyginti su placebo grupe, pailgejo laikas iki pirmojo LOPL paūmèjimo: tiotropio grupejje laiko iki paūmejjimo mediana buvo 16,7 mèn., o placebo grupejje 12,5 mèn. Tiotropio grupeje 14 proc. sumažèjo vidutinis paūmejjimu skaičius vienam pacientui per metus (santykinè rizika (SR) - 0,86, 95 proc. PI 0,81-0,91; $\mathrm{p}<0,001)$, palyginti su placebu. Be to, ženkliai suretėjo paūmèjimų, kai reikalingas stacionarinis gydymas, (SR 0,86; $\mathrm{p}<0,002$ ), palyginti su kontroline grupe.

Gydant tiotropiu, statistiškai reikšmingai (14 proc.) pailgejo laikas iki pirmojo hospitalizavimo dèl LOPL (SR 0,86, 95 proc. PI $0,78-0,95$ ). 


\section{Mirštamumas}

Išanalizavus visų ketintų gydyti pacientų (iskaitant pirma numatyto laiko nutraukusių tyrimą) 4 metuc ir 30 dienų laikotarpio (1 470 d.) duomenis, nustatyta, kad mirè 941 pacientas: 14,9 proc. tiotropio ir 16,5 proc. placebo grupèse (SR - 0,89, 95 proc. PI, 0,79-1,02; $\mathrm{p}=0,09$ ).

Analizuojant tik tyrimo laikotarpi (1 440 d.) ir pacientus, apie kurių gyvybinę būklę gauta duomenų, nustatyta, kad mirè 921 pacientas: 14,4 proc. tiotropio ir 16,3 proc. placebo grupèse. Tai statistiškai reikšmingas skirtumas (SR - 0,87, 95 proc. PI, 0,76-0,99).

Statistiškai reikšmingas 16 proc. mirties rizikos sumažẻjimas ( $\mathrm{p}=0,016)$ nustatytas tiotropi vartojusių ligonių grupeje. Šis rodiklis nepakito net ir tada, kai analizuojant rezultatus, buvo įskaičiuotos mirtys pacientų, prieš laiką nutraukusių dalyvavimą tyrime ( $\mathrm{p}=0,034)$. Mirties rizikos sumažèjimas buvo vertintas ir praejus 30 dienu po tyrimo pabaigos, tačiau gautas skirtumas nebuvo statistiškai reikšmingas $(\mathrm{p}=0,086)$.

\section{Gyvenimo kokybè}

Tiotropis statistiškai reikšmingai pagerino gyvenimo kokybę, nustatytą pagal St. George kvėpavimo ligų klausimyną (SGRQ, $\mathrm{p}<0,001)$. Pacientu, vartojusių tiotropi, ivvairiu laiku per ketverius metus gyvenimo kokybė buvo geresnè nei tyrimo pradžioje.

\section{Vaisto saugumas ir šalutinis poveikis}

Šalutinių reiškinių buvo užregistruota 92,6 proc. tiotropio grupès tiriamųju ir 92,3 proc. placebo. Kaip ir ankstesniuose tiotropio tyrimuose, dažniausias šalutinis poveikis - burnos džiūvimas.

Pabrèžtina, jog tiotropis sumažino sergamumą kvépavimo $(\mathrm{p}<0,05)$ ir širdies ligomis $(\mathrm{p}<0,05)$.

\section{APIBENDRINIMAS}

Didelis LOPL sergančių pacientų tyrimas UPLIFT parodé, kad LOPL pacientuc, jau gydomu kitais iprastiniais vaistais, gydymas tiotropiu nors nesumažina šiai ligai būdingo plaučiu funkcijos (tiriant $\mathrm{FEV}_{1}$ ir FVC) blogejimo spartos, bet, palyginti su placebu:
- reikšmingai pagerina plaučių funkcijos rodiklius;

- reikšmingai pagerina su sveikata susijusią gyvenimo kokybę;

- statistiškai reikšmingai pailgina laiką iki pirmojo LOPL paūmèjimo, 14 proc. sumažina hospitalizavimo dèl LOPL paūmèjimo riziką, 14 proc. sumažina vidutinị paūmèjimų skaičių vienam pacientui per metus;

- turi tendenciją mažinti mirštamumą;

- yra saugus, sumažina sergamuma kvėpavimo sistemos ir širdies ligomis. Geri sergančiųju antros stadijos LOPL gydymo tiotropiu rezultatai pagrindžia klinikinejje praktikoje skiriamą ilgalaikị gydymą tiotropiu jau ankstyvuoju ligos periodu.

\section{LITERATŪRA}

1. D. P. Tashkin, B. Celli, S. Senn at al. A 4-year trial of tiotropium in chronic obstructive pulmonary disease. New Engl J Med, 359:15, 2008.

\section{BŪSIMŲ RENGINIŲ KALENDORIUS}

\begin{tabular}{|c|c|c|}
\hline Data & Renginys & Vieta \\
\hline 2009-02-15-18 & $\begin{array}{l}\text { 9-asis kasmetinis simpoziumas: šiuolaikinè } \\
\text { koncepcija pulmonologijoje ir skubiojoje pagalboje }\end{array}$ & Havajai, JAV \\
\hline 2009-03-13-17 & $\begin{array}{l}\text { Kasmetinis AAAAI (angl. American Academy of } \\
\text { Allergy Asthma and Immunology) susitikimas }\end{array}$ & Vašingtonas, JAV \\
\hline 2009-03-26-29 & $\begin{array}{l}\text { Pirmasis Vidurio Rytu ir Azijos alergijos, astmos ir imunologijos } \\
\text { kongresas }\end{array}$ & Dubajus, Jungtiniai Arabų Emyratai \\
\hline 2009-03-27-29 & $\begin{array}{l}\text { 7-oji ERS (angl. European Respiratory Society) plaučių mokslo konfer- } \\
\text { encija. Ląstelių proliferacija, diferenciacija ir karcinogenezé }\end{array}$ & Estorilis, Portugalija \\
\hline $2009-05-15-20$ & Tarptautinè ATS (angl. American Thoracic Society) konferencija & San Diegas, JAV \\
\hline 2009-05-29 & $\begin{array}{l}\text { LPAD konferencija „Pulmonologija, alergologija ir klinikinè imunologi- } \\
\text { ja - 2009“, skirta Lietuvos tūkstantmečiui }\end{array}$ & Kaunas, Lietuva \\
\hline 2009-05-29-06-02 & $\begin{array}{l}\text { ASCO (angl. American Society of Clinical Oncology) metine } \\
\text { konferencija }\end{array}$ & Orlandas, JAV \\
\hline $20090606-10$ & $\begin{array}{l}\text { 28-asis EAACI (angl. European Academy of Allergology and Clinical } \\
\text { Immunology) kongresas }\end{array}$ & Varšuva, Lenkija \\
\hline 2009-06-11-15 & $\begin{array}{l}\text { FOCIS (angl. Federation of Clinical Immunology Societies) metinè } \\
\text { konferencija }\end{array}$ & San Franciskas, JAV \\
\hline $2009-06-17-20$ & 10-asis tarptautinis plaučių vėžio kongresas & Kohala pakrantè, Havajai, JAV \\
\hline $2009-07-22-26$ & $\begin{array}{l}\text { Imunologijos mokslinè tarptautinè FIRN (angl. Frontiers in } \\
\text { Immunology Research Network) konferencija }\end{array}$ & Havajai, JAV \\
\hline $2009-07-31-08-04$ & Pasaulinė plaučių vèžio konferencija & San Franciskas, JAV \\
\hline 2009-09-12-16 & ERS (angl. European Respiratory Society) metinis kongresas & Viena, Austrija \\
\hline 2009-09 & Kasmetinè rudens LPAD konferencija & Lietuva \\
\hline $2009-09-22-25$ & $\begin{array}{l}\text { INTERASTHMA (angl. International Association of Asthmology) } \\
\text { konferencija }\end{array}$ & Kanarų salos, Ispanija \\
\hline 2009-10-31-11-05 & $\begin{array}{l}\text { CHEST (angl. American College of Chest Physicians) metinè konfer- } \\
\text { encija }\end{array}$ & San Diegas, JAV \\
\hline 2009-12-03-07 & 40-oji jungtinė pasaulio plaučių ligų konferencija & Kankunas, Meksika \\
\hline $2009-12-06-10$ & 21-asis WAO (angl. World Allergy Organisation) kongresas & Buenos Aires, Argentina \\
\hline
\end{tabular}

